\title{
Factory Farms in a Consumer Society
}

\section{Chad Lavin}

Originally conceived in response to the industrialization of American agriculture, the term "factory farm" became an increasingly popular metaphor in American culture through the twentieth century. While agricultural engineers could be heard using the term in heralding the efficiency and predictability of large and wisely managed farms, critics used the term to signal a threat to the more bucolic "family farm" that evoked so many images of honest work, self reliance, and national identity. As a result, the metaphor quickly became pregnant with concerns about individual autonomy and national integrity that far exceeded the specific concerns of industrial farming.

This essay examines the emergence and transformation of the metaphor of a factory farm in the twentieth century. Developed to describe a specific trend in agricultural organization, the metaphor today travels freely and is found in discussions of multiple domains of life, from industrial feedlots, to white-collar workplaces, to retail outlets, to individual bodies. This expansive use of the metaphor reflects the extension of disciplinary technologies to domains of life beyond those exemplified by the industrial workplace. In particular, technologies familiar from workplace management today extend to private and retail spaces, such that people are disciplined in their role as consumers as much as their role as workers. I argue that the metaphor calls attention to the powerlessness of citizen-consumers under globalization, but then lends itself to a politics that calls upon those same citizen-consumers to take responsibility for political change. 


\section{Down on the Factory}

Though the specific origin of the term "factory farm" is unknown, it certainly becomes noticeable in the first half of the twentieth century, as the mechanization, division of labor, and intensified regulation of activities endemic to industrial manufacture begin finding expression on American farms. While today the term is used almost exclusively in critiques of agribusiness, earlier usage was clearly more optimistic, heralding the potential benefits of applying the scientific knowledge of management and organization to farms. From within the perspective of industrial progress, the factory farm promised greater efficiency, higher crop yields, and more predictable commodities markets. As one agricultural engineer wrote in 1917:

Nobody will object to calling a farm a factory. It is a factory. The soil and the seed are the raw materials, and from these are manufactured a variety of finished products, through the agencies of sun, air, moisture, power, and implements. The finished products of the farm factory are cereal, forest, vegetable, and fruit crops, and livestock and livestock products, are they not? (quoted in Fitzgerald 2003, 109)

It was not always clear, however, what this terminological development signaled in terms of concrete agricultural practices. Writing nearly three decades earlier, economist Alfred Marshall offers a brief discussion of factory farming that suggests the transformation will be more quantitative than qualitative. Closing the section of his Principles of Economics that focuses on large-scale industry, Marshall (1890/1961) writes: "Our knowledge on many disputed points would be much increased . . . if some private persons, or joint-stock companies, or co-operative associations, would make a few careful experiments of what have been called "factory farms" "(652). ${ }^{1}$ From his hypotheses, however, it is clear that Marshall might just as well have said "large farms" instead of "factory farms," since he proceeds to describe this new possibility as differing only in size, not in technique, from traditional family farms. He thus questions the feasibility of factory farms on three accounts. First, farming requires large pieces of land, and the amount of land required increases proportionately to the farm's productivity. Second, agriculture is dependent upon the seasons, which interferes with the aggressive investment of capital. Third, agriculture is not characterized by a division of labor as industrial manufacture is.

Clearly, Marshall was mistaken about each of these limitations. With regard to the inflexibility of land use, the natural limitations on crop density arising from soil fertility and threats of parasites have been largely overcome with the development of industrial fertilizers and pesticides. Soil management, crop rotation techniques, and the introduction of gasoline-powered farm equipment (allowing farms to grow commodity crops on land formerly required to raise fuel 
for working livestock) have also increased the productive potential of discrete parcels of land. With regard to seasonal restrictions on farming, developments in irrigation, insulation, and air conditioning allow farmers to create isolated ecosystems, manipulating both animals and crops to grow in response to artificial calendars. Finally, industrial harvesting today utilizes the same division of labor evident in more conventional assembly lines, though with the difference that it is often the worker on a tractor that moves down the line of stationary products.

These developments that Marshall did not foresee arose in large part from systematic attempts to bring the principles of scientific engineering to bear on American farms, attempts that coincide with the development of new disciplines of academic and professional knowledge today known as agricultural engineering. In her study of U.S. agriculture in the first three decades of the twentieth century, Deborah Fitzgerald (2003) details the rise of academic attention to farm practices coming out of the newly established land-grant universities. Agricultural engineers (represented in the American Society of Agricultural Engineers, est. 1907), agricultural economists (working primarily with government to develop wise agricultural policies), and farm managers (working with farmers to maximize efficiency) transformed not only the size of farms, but also how the activities would be organized on them, promoting intensified attention among farmers to bookkeeping, efficient land use, and climate control. These managerial and scientific developments, owing less to the decisions of individual farmers to industrialize than to an economic imperative to compete with the recently collectivized Soviet farms on the international wheat market, provoked the first major shift towards factory farming in the United States (Fitzgerald 2003, 157183).

These changes also provoked the second significant shift toward the factory model in U.S. farming: capital concentration. Because investing in these technologies required large quantities of capital, this period saw banks becoming more directly involved in family farms. As industrial technologies lend comparative advantage to larger farms over smaller ones, the period saw mergers and expansions of farms along with larger and more numerous mortgages on the growing farms. Closely followed by drought, economic downturn, and war-induced labor shortages, this consolidation led to what is now known as the farm crisis of 1919, with numerous farm foreclosures and much of the agriculturally-friendly Western land coming under the ownership of banks rather than farmers (Fitzgerald 2003, 17-30).

Though this systematization and financialization of farming largely took hold in the pre-war period, the third major shift to factory farming did not emerge until the middle of the twentieth century. The discovery of antibiotics in the 1940s and their relatively quick introduction into the agricultural community helped to overcome one of the primary obstacles that Marshall identified with regard to the inflexible demands of land. Prior to this development, the dense concentration of livestock now common on the industrial feedlot was simply impracticable 


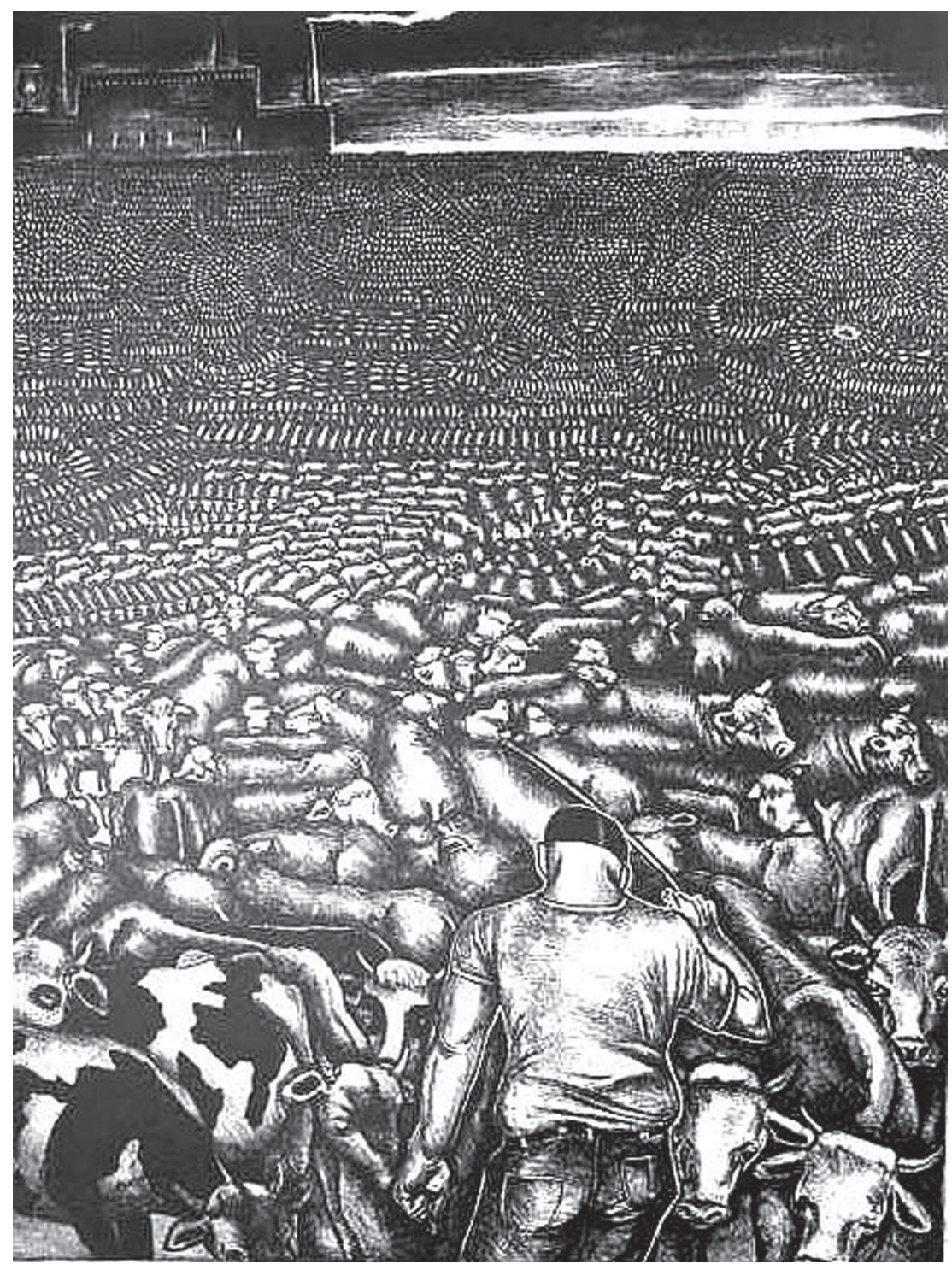

Figure 1: Sue Coe, Feed Lot, (suecoe copyright 2009).

as it proved to invite widespread animal epidemics that could quickly destroy a breeder's entire inventory. As with human communities, disease spreads at exponential rates as populations grow more dense (since encounters with infected animals becomes more frequent) and sedentary (since this means living in relative proximity to large quantities of urine and feces). ${ }^{2}$ Finally, antibiotics allow livestock to endure dietary regimens that tremendously accelerate their growth, 
allowing ranchers to bring animals to maturity and slaughter weight more quickly and thus increasing the turnover of their inventory. ${ }^{3}$

Of course, despite the optimistic and triumphal rhetoric of agricultural engineers, this organization, concentration, and medicalization of farming did not occur without criticism. Fitzgerald chronicles popular disenchantment with factory farming from its earliest days, with common concern being voiced that factory farming poses a threat to the moral as well as economic health of the nation, displacing family farmers and homogenizing the mythologized American west $(2003,124)$. This critique is still visible today, but it is increasingly rare and unwieldy. Since the situation of displaced family farmers parallels that of many putatively anachronistic professions in today's economy, questioning how farmers have fared in the transformation from a yeoman to an industrial agriculture typically entails questioning the logic of industrial capitalism itself. So, for example, when Eric Schlosser links the industrialization of cattle farming to high bankruptcy (and thus suicide) rates among American ranchers; he also shows how market pressures have reduced ranchers - those embodiments of American autonomy and rugged individualism - to the indentured servants of four meatpacking firms (2001, 133-148). Similarly, in studying the economics and operations of an industrial feedlot, Michael Pollan chronicles how ranchers must violate their tradition, their conscience, and the principles of economic selfdetermination in following the demand of corporate meat processors to inject their animals with large doses of hormones and antibiotics $(2002,2006,65-84){ }^{4}$ Subsistence hunter Richard Manning laments that his grandfather was in "the last generation of farmers to have ... independence, before it got traded away for efficiency" (2004, 86, 130-5). Echoing the concerns that Fitzgerald chronicles from a century ago, these arguments find the American rancher, a figure second perhaps only to the cowboy for its investment in American identity and authenticity, subject to the dictates of international corporations. Factory farming is, in other words, un-American.

Such wide-reaching critiques of industrialization and capital concentration, however, have rarely been more than marginal in American politics. As such, it is probably no surprise that the metaphor of a factory farm rarely extended beyond the literature of agricultural engineering until the 1960s, when the shifting techniques of animal husbandry pursuant to the discovery of antibiotics and the increased use of chemical pesticides reinvigorated concerns with animal welfare and industrial pollution. ${ }^{5}$ Since then, critics of factory farming have paid less attention to the economic well-being of farmers (both as individual citizens and as symbols of American autonomy), instead focusing on more fashionable issues of ecological sustainability and ethical awareness.

This ecological trend begins with Ruth Harrison (1964), who opens her path breaking Animal Machines by introducing readers to a "new type of farming" that applies "production line methods ... to the rearing of animals" (1). Though Harrison frets that animals are being treated as mere "food converting machines" (3) and her opposition is couched in the rhetoric of justice and animal rights, 
she ultimately focuses less on animal welfare and more on ecological issues of contamination in the industrial food supply. "Modern techniques of farming ensure the contamination of food right from its beginning," she declares, with industrial food processing increasing the poisons (pesticides, preservatives, dyes) and decreasing the nutrients in our commercially available food (112). "Intensification of livestock rearing has simply taken all these hazards a stage further," she continues, "and in my opinion made the food a definite danger to consumers" (113); in short, "Unhealthy animals cannot make healthy food for humans" (115). Harrison, in other words, uses the metaphor of a factory farm to convey a general ecological concern about industrialization. Her criticisms apply freely to industrial water and air pollution; meat is but one very visible manifestation of the threat. ${ }^{6}$

By way of ethical critiques, the high-water mark would have to be Peter Singer's (1975) Animal Liberation. Avowedly utilitarian and brusquely vegetarian, Singer argues that management techniques such as "assembly-line methods" and issues of scale have transformed "agriculture [in] to agribusiness" and animals into "machines that convert low-priced fodder into high-priced flesh" (96-7). Singer steadily deploys the factory metaphor through this book, describing how chickens are transformed "from farmyard birds into manufactured items" (98); a hen becomes "an egg-producing machine ... an efficient way to turn feed into eggs" (107); a pig becomes "a living reproduction machine ... a "valuable piece of machinery whose function is to pump out baby pigs like a sausage machine" (126); a dairy cow is "a carefully monitored, fine-tuned milk machine" (137). The industrial meat supply, Singer argues, arises from barbaric (if technologically savvy) treatment of animals, and consumers are more-or-less directly implicated in this barbarism.

The common theme of these critiques, similar to others of industrial life, is that the pursuit of efficiency causes great harm to people, animals and the environment. At the same time, critiques of factory farming frequently demonstrate how recalcitrant the drive for efficiency is, by simply inverting — rather than troubling or rejecting - the industry's claims. Jeremy Rifkin, for example, attributes the profitability of large-scale beef production to federal land grants, with industrial ranchers receiving 30 million acres of public land free of charge, and another 300 million acres at 20-25 percent of its market value (1992, 100-111). Richard Manning calls factory farming "a living, continental-scale monument to Rube Goldberg"- a system cloaked in efficiency claims that are only defensible so long as one does not account for increasing reliance on federal subsidies, fossil fuels, and tolerance for environmental runoff $(2004,2004 a)$. This move is surprisingly evident in even the most sentimental and wholesome of attacks on "Big Food." Though Frances Moore Lappé's canonical reveille Diet for a Small Planet (1971) is largely an indictment of supermarkets and processed foods for inhibiting the natural and authentic lifestyle so stereotypical of a Berkeley transplant of her period, it does not argue against the pursuit of efficiency, but instead that a meatbased diet is inefficient; requiring sixteen pounds of grain to produce one pound 
of beef, livestock is "A Protein Factory in Reverse" (70). Similarly John Robbins (1987) argues in the popular vegetarian manifesto Diet for a New America that factory farming is "a drastically inefficient use of our acreage" (351). Even Peter Singer gets on the efficiency train, casting veal less as a moral abomination and more as a sheer waste of calories $(1975,129)$. Such arguments focus less on the dehumanization and myopia endemic to a blind pursuit of efficiency, and more on the mechanisms, regulations, and calculations that allow such uneconomical practices to look profitable on crude balance sheets.

Whether they reject or merely invert the value of efficiency, each of these critiques speak to a generalized anxiety about the possibilities for freedom and self-control. The ecological critique does not merely raise concerns about environmental stewardship, it notes that with a corrupted food supply individuals have lost the ability to decide which pollutants and toxicants they will ingest. The ethical critique does not merely exploit images of animal suffering in support of vegetarian agenda, it insists that the opacity of commodity markets severely limits the ability of consumers to buy products that live up to their own ethical codes. The economic critique does not merely raise concerns about worker exploitation, it calls attention to how both producers and consumers are coerced by market imperatives to engage in practices they would otherwise find repellent. ${ }^{7}$ Each, in other words, attempts to demonstrate how the pursuit of agricultural efficiency prevents workers, owners, and consumers from living on their own terms.

Of course, these economic, ecological, and ethical critiques are not mutually exclusive. In fact, they often converge when considered in the broader context of global politics as, for instance, when Michael Pollan endeavors to link the ecological, ethical, and economic concerns about factory farming to key political decisions orbiting around the Cold War and the current situation in Iraq (2006, 32-56). Examining the history of a singular crop, corn, Pollan details how Nixon's 1972 attempt to best the Soviets by offering vast subsidies to corn farmers fundamentally changed American agriculture. Encouraging farmers to plant their fields "fencerow to fencerow," this policy provoked a vast overproduction that remains to this day and that has resulted, Pollan argues, not only in tons of wasted corn and depleted topsoil, but in a vibrant industry in finding new and economical uses for the "cheap" grain. As an artificial sweetener, as animal feed, and as a binding agent in most processed foods, corn has become the sine qua non of the soft drink, beef, and fast food industries. And insofar as vast and uniform cornfields survive only with the heavy use of petroleum-based fertilizers and pesticides, he reads the U.S. military presence in the Middle East as an unspoken subsidy for these industries - a subsidy that has allowed hamburgers and soft drinks to grow increasingly larger while maintaining remarkably stable retail prices of around $\$ 1$ each. As a final cost, insofar as corn overproduction allows junk food and soft drinks to retail for less than fresh produce and milk, Pollan argues that the true cost of corn overproduction would have to include the increased healthcare expenditures stemming from rising rates of obesity and type 2 diabetes. 
Arguments like this locate the stakes of the factory farm debate well beyond the treatment of crops and animals. Linking obesity to the Cold War and fast food to Iraq, Pollan suggests that all manner of apparently free choices are traceable to the economic and technological organization of agriculture. Farmers are the first casualty in Pollan's work; they mistreat their animals and work against their own economic self interest because they are coerced by agribusiness. Consumers hardly fare any better; their health and lifestyle arise not from freely developed preferences about diet and exercise, but from the arbitrary availability and exploitability of particular foodstuffs. Pollan finally attacks the logic of national self-determination, rooting domestic and international policy not in the representative will of a population, but in the overwhelming imperatives of global food markets. In this argument, the spoils of factory farming are not only a breached ethical covenant with animals and unsustainable agricultural policy, but also a subordination of human life itself to a corporate pursuit of efficiency. In Pollan's hands, the factory farm metaphor upsets the familiar myths of freedom and self-determination from American ideology, placing the American individual in a set of relations no less managed than the aesthetically pleasing-if ecologically devastating — crop monocultures that increasingly dominate the American landscape.

\section{Who's Afraid of Factory Farming?}

The previous section shows how the metaphor of a factory farm came to capture a set of anxieties surrounding the development of industrial agriculture over the past century. But while the economic, ecological, and ethical critiques of factory farming are certainly grounded in the specific intensifications of farming practices, they also have significant bearing on the development of other industries and lifestyles. As such, the form and content of these critiques soon travelled well beyond the realm of agriculture and evoked a broader trend in the social and political organization of the American landscape, consolidating concerns about the welfare of not only farmers, environmental sustainability, and animal rights, but also workers, consumers, and citizens more generally.

By the end of the twentieth century, the metaphor of a factory farm had taken on a life of its own and found its way into pop cultural artifacts bearing little relationship to food. One sees the metaphor in narratives of white-collar alienation, such as Douglas Coupland's epochal novel Generation X (1991) in which moribund college graduates work in cubicles described as "veal fattening pens." It also animates dystopian techno-fantasies, such as The Matrix films in which human bodies are cultivated as bio-fuel for a post-human order in which, as one character explains, "There are fields, ... endless fields where humans are no longer born. We are grown." "Only slightly less overtly, the image of human beings as so many products of factory farms organizes allegories of race, imperialism, and capitalism such as Octavia Butler's Dawn (1987), in which human survivors of a nuclear holocaust are selectively bred with an alien race like so 
much livestock, and Kazuo Ishiguro's Never Let Me Go (2005), in which human beings are literally cloned and then harvested for their organs.

Works like these mobilize the familiar metaphor of a factory farm to describe a mode of organization that far exceeds the operations of industrial agriculture. The factory farm works as what Lakoff and Johnson call a "structural metaphor," a figure of speech that uses "one highly structured and clearly delineated concept to structure another" (Lakoff and Johnson 1980, 61). Such metaphors, they argue, are "grounded in systematic correlations within our experience" and they achieve prominence in our language because they correspond to an "experiential gestalt" $(1980,61,81)$. Structural metaphors, in other words, do not felicitously or efficiently describe one aspect of our daily lives, but rather evoke a dynamic that extends to more general conditions of existence. In the movies and books mentioned above, the metaphor of a factory farm resonates with a sense of confinement and standardization endemic to contemporary society. Unlike earlier critiques of alienation and industrial life in which workers were placed alongside or subordinate to machines, these narratives introduce the factory logic to the very organic operations of the body itself, and they use the metaphor to structure an understanding of various institutions: from work and school to mass media and global commerce.

Lakoff and Johnson's argument parallels Mary Douglas's (1966) explanation of social taboos as expressing general preferences for social order; the prohibitions on eating "unclean" animals in Leviticus, for instance, have little to do with hygiene or nutrition, but reflect "an elaborate intellectual structure of rules that mirror God's covenant with his people" (xv). It also replicates Marx's critique of ideology. For despite the typical vulgarization of ideology as "false consciousness," Marx does not argue that ideology is wrong, but that it can be explained by the material situation in which it takes hold. Ideology is, in a sense, entirely too right. The Hegelianism that reduces individuals to the expression of an external force resonates with the material situation in which workers do not decide what they will do with their lives (Marx 1843/1970, 130-142); an ideology of individualism makes sense under the material conditions of yeoman farming in which individuals sustain themselves by their own labors, but is destined to be replaced by class consciousness in a society characterized by an industrial division of labor in which survival depends upon regular cooperation (Marx 1867/1977, 439-454). Structural metaphors, like taboos and ideologies, are rooted not in any particularly idiosyncratic institution or experience, but in the broad dynamics of an historical period; they work not by revelation, but by analogy.

The appeal of the factory farm metaphor does not come from its unique ability to describe a specific institution, but from its ability to capture an organizational logic that pervades the experiential gestalt of late capitalism. It evokes the sense that the organization of work, leisure, and politics compels homogenous and impersonal (anomic, though useful) interactions, such that individual units pass rapidly, anonymously, efficiently, and systematically through a series of 
processes and emerge relatively indistinguishable from one another. The anxieties about imprisonment, surveillance, management, and exploitation that inhere in the metaphor have their bite not in the treatment of crops and animals, but in workers being housed and watched in cubicles; in consumers being monitored and managed via data mining and niche marketing; and in citizens being tracked through government wiretaps and privately owned surveillance cameras. The books and movies just mentioned evoke a series of technologies and institutions that threaten conventional ideals of freedom in the social and political landscape of global capitalism, a landscape comprising such ubiquitous surveillance that the dominant theme in popular media - from reality television to Facebook - is voyeurism, and such pervasive behavioral management that a full 50 percent of Americans take at least one prescription medication every day (Critser 2005; Moynihan and Cassels 2005).

The books and movies just mentioned demonstrate an experiential gestalt in which concerns about coercion, alienation, and exploitation endemic to critiques of factory labor are felt across social life. Allegorically and indeterminately deploying the factory farm metaphor to describe the workplace, the economic order, the state, culture, school, or, as in The Matrix, merely "The System," these works draw attention to the parallel logics structuring activities across the domains of social life. They thus find wide resonance not with pervasive concerns about industrial agriculture - practices which few of us ever encounter and so can relatively easily ignore - but with the experiential gestalt of global capitalism. ${ }^{9}$ It is probably no coincidence that the term "factory farm" became one of derision in the 1960s, when critiques of mass society and technocratic rationality exemplified by the Frankfurt School were on everybody's plate.

Today, the literature on globalization almost invariably invokes this gestalt. The refrain on globalization, by now familiar to the point of axiom, is that the mobility of information and capital threatens national sovereignty and thus individual freedom by subordinating the judgment of supposedly representative states to the dictates of international finance organizations and multinational corporations. When national solvency requires accepting the prescriptions of the World Bank and the IMF, when localities surrender the right to regulate trade and arbitrate disputes to the WTO, and when the persistent threat of capital flight allows corporations to effectively dictate national policies, laws appear less the expressed interest of a territorially bound population than the codification of the interests of unrepresentative groups. Globalization, that is, calls into question the legitimating conceit of liberal governance: that the state facilitates freedom by ensuring that individuals live according to laws that they choose (albeit indirectly). This leads theorists of globalization to ask whether we are Losing Control? (Sassen 1996), and whether there are any institutions that might offer accountable governance in the absence of sovereign states (e.g., Hardt and Negri 2000, 2004). In this literature, what is at stake is the very possibility of self-governance, as citizens become powerless pawns in a world controlled by corporate interests. 
This gives context to the pervasive anxieties about powerlessness and coercion that inhere in the factory farm metaphor. Harrison's concern about the ubiquity of industrial poisons, Singer's concern about the ethical responsiveness of industrial farming, Schlosser's concern about ostensibly sovereign economic agents becoming little more than indentured servants of international corporations, Pollan's focus on the legislative and economic roots of obesity and international war, and the concerns about institutional power expressed in Generation $X$ and The Matrix - these all appeal to an anxiety about the ability to control the course of one's own life. The multiple and various articulations of the metaphor, in other words, resonate with the experience of powerlessness of workers, consumers, and citizens that is the dominant theme of discussions of globalization. This wide usage is emblematic of a structural metaphor that uses one highly delineated concept to structure another. It is also emblematic, as I will discuss in the final section of this essay, of trends in food politics today which endeavor to tie the most intimate of individual choices (what one puts in their body) to the most far-reaching issues of democratic control and environmental sustainability.

\section{From Jungle to Nation}

The factory was not always such a central metaphor in American life, and "factory farm" is just one of a series of industrial metaphors that came to occupy American discourse around the turn of the twentieth century. Anson Rabinbach (1990) chronicles a variety of discourses at this time figuring the body as a "human motor" that could be managed and exploited for maximum efficiency. In contrast with an earlier period in which concerns about order and productivity were anchored in moralistic assumptions about idleness and character (see Weber 1904/1930), Rabinbach shows how these new industrial metaphors focused instead on the physical threat of fatigue. In this optimistic age of apparently unlimited capacities for industrial growth, the primary threat to social order and economic prosperity was not moral dereliction, but rather physical exhaustion. Ever since, management and nutritional discourses have focused less on motivation and more on efficiency.

The typical touchstones in this shift are John Harvey Kellogg and Charles W. Post who were, at the turn of the twentieth century, promising to cure industrial "neurasthenia" through a strict, ascetic regimen of fiber, rest, sobriety, and enemas that would attack the "blockage" of the typical American colon. Characterizing the body as a machine, Kellogg and Post developed and promoted foods specifically designed smoothly and efficiently to pass through the human digestive system, leaving behind as many nutrients as possible without obstructing an ideally frictionless process of nutritional absorption (see Levenstein 1993; Boyle 1993). This is also when Americans were first advised that food should be measured not by weight or bulk, but by how much energy it delivered; the popular bestseller How to Live (Fisher and Fisk 1915) was among the first texts 
explaining that the key to weight loss, physical efficiency, and general health was in paying attention to "fuel-units, called calories" (28). ${ }^{10}$

Around the time Kellogg was attending to society's upper crust, the United States also saw the release of what would become the undisputed zenith of twentieth-century food writing, Upton Sinclair's The Jungle (1906a). Sinclair presents a two-pronged attack on the American food industry, revealing how the pursuit of efficiency in the industrial slaughterhouse has created a food system that is both unsanitary and unconscionable. In Sinclair's narrative, the meat industry profits off of not only dissected cattle carcasses, but also the spilled blood and destroyed muscle tissue of the workers in its factories. Industrial machinery manipulates and actually mixes with human bodies, as workers do not just engage with machinery, they fuse with it; tools are wielded like prosthetic limbs, while knives enter and destroy the bodies of workers as well as cattle. In Sinclair's food factories, the line between fixed and variable capital is fluid, as is the line between producer and product, machine and commodity - most memorably via the allegation that workers' bodies are occasionally rendered into and sold as lard. Widely credited with inspiring the Federal Meat Inspection Act and the Pure Food and Drug Act (both 1906), The Jungle is one of the earliest and most successful attempts to draw attention to the ills of industrial capitalism by telling a story about industrial food.

If there is a contemporary equivalent to Sinclair's muckraking report on slaughterhouses, it would have to be Eric Schlosser's Fast Food Nation (2001) or perhaps Morgan Spurlock's film Super Size Me (2004). Notably, these works each shift attention away from the industrial production of food toward its commercial marketing and consumption. Like Sinclair, Schlosser and Spurlock look at our food supply to show how concentrations of capital threaten individual health and freedom. But while Sinclair taps into an anxiety about this threat through the example of the industrial factory, Schlosser and Spurlock start with fast food franchise. That is, Sinclair looks at the food industry as a mode of production, Schlosser and Spurlock as a mode of consumption; Sinclair focuses on threat while we're working, Schlosser and Spurlock on threat while we're eating. In the one hundred years between The Jungle and Super Size Me, the concerns about coercion and health were redirected from work to leisure, from the boss to the value meal.

Of course, millions (indeed, most) Americans still work in factories-industrial, retail, and agricultural factories. And to be sure, Schlosser does write about the brutal and dehumanizing labor of farms, feedlots, and slaughterhouses. He also talks about McDonald's as a place where people work, not just eat. His descriptions of how food is "assembled" (certainly not cooked, or even prepared) by robotic mechanisms, compressed carbon dioxide, conveyor belts, and automatic sensors are clearly intended to evoke the traditional operations and images of industrial manufacture (66-70), and the product, "a small, rectangular, hand-held, frozen, reheated apple pie" (3), is just one among many standardized, manufactured commodities. 
But from the opening of the book, it is clear that Schlosser wants to talk about how the fast food industry extends the rhetoric and techniques of industrial manufacture to figure not just the worker's body, but also the consumer's body, as a machine. For Schlosser, it is how we eat - rather than how we work - that reveals our national spirit (3), and throughout the book, he deploys the familiar tropes of industrial manufacture to describe practices of consumption as well as production. In Fast Food Nation, it is both workers and consumers that are regulated by television monitors and computer software (66-70), and Schlosser characterizes the manufacture as well as the purchase and consumption of fast food as a series of routinized behaviors and rhythmic actions (3). For Schlosser, the industry depends on not only the interchangeability of parts and workers familiar from traditional discussions of industrial manufacture, but also the interchangeability of customers (70). In other words, he describes the fast food outlet as a factory in which both our production and consumption is subject to the principles of Taylorist management.

Schlosser's description of the technologies leading to the Chicken McNugget - technologies that "turned a bulk agricultural commodity [a bird] into a manufactured, value-added product" $(2001,139)$ — not only echo those of Harrison and Singer from a previous generation, but also directly parallel his description of Greeley, Colorado- a ranching community "where cattle are the main units of production, where workers and machines turn large steer into small, vacuum-sealed packages of meat" (149). His chapter on Greeley is called, in an explicit nod to Sinclair, "Cogs in the Great Machine," and this chapter marks a shift in the book from talking about factory farms to talking about "a modernday factory town" (149). This term carries a double meaning for Schlosser, as he draws on the traditional meaning in which a town's livelihood depends on one particular business and on the idea that the town itself functions as a factory, with cattle and workers as the capital, and "crime, poverty, drug abuse, and homelessness" the end product (149). ${ }^{11}$

Schlosser uses the same terms to describe what happens in the slaughterhouse as to describe what happens around the slaughterhouse and to describe what happens at your local burger franchise. Alongside the uniform and routinized actions characteristic of the fast food shopper, Schlosser uses parallel constructions to describe the actual factory potato farm, labor in an industrial slaughterhouse, the predictable shopping patterns of the American consumer, and the political machinations ensuring the profitability of these enterprises. In other words, Schlosser applies the industrial terminology to the animal's body, the farm that houses it, and the society that consumes it. As he proceeds to discuss the marketing and metabolism of junk food, one cannot help but notice how the factory logic is now in operation in the body of the consumer, converting calories into fat and advertisements into capital. 


\section{Producing Consumers}

This shifting site of concern - from the industrial factory to retail outlet, from work to leisure, from production to consumption - reflects a shifting set of material realities. Michel Foucault's work on disciplinary institutions and human sciences can guide us through the first half of the story; in Discipline and Punish (1977), Foucault explains how teachers, jailors, and bosses confine, observe, examine, and exercise bodies so as to make them both functional and predictable. This is what he means by discipline, and this is exactly what we see in Sinclair's slaughterhouse - workers are confined, observed, examined, and exercised so as to learn about, organize, and control their bodies. But it is less clear how much Foucault helps us understand the second half of the story which is seemingly defined by a move away from panopticism to consumerism. While Discipline and Punish effectively grasps the Taylorism ascendant in the early twentieth century, it is less clear how relevant the book is at the opening of the twenty-first, when labor is increasingly casual, flexible, and outsourced, accomplished less by confined employees and more by mobile temps, telecommuters, and independent contractors working from internet cafes.

In "new business" writers like Tom Peters $(1992,1999)$, this relaxing of the hierarchical authority of the traditional workplace unleashes the creative potential of employees and deserves to be described with words like "liberation" (cf. Frank 2000, 170-219). But the idea that the casualization of labor throws into question the significance of traditional sites of disciplinary authority is not restricted to such bourgeois apologias. Hardt and Negri (2000, 23-7), for instance, also argue that the declining significance of institutions like industrial factories marks a break with Foucault's disciplinary society. Today, they argue, because work does not happen in specific and enclosed spaces, Foucault's focus on the material organization of bodies on assembly lines, in hospitals, and in classrooms appears increasingly anachronistic. Foucaultian discipline "fixed individuals within institutions" and so only functioned episodically and in specific locations $(2000,24) .^{12}$

Today, Hardt and Negri see an increasingly smooth social space with less of a distinction between "at work" and "at home." But they argue that this casualization of labor does not entail an emancipation from Foucaultian discipline so much as its "intensification and generalization" (2000, 23). Now, individuals are monitored and regulated not only when they visit the factory, schoolhouse, or hospital, but also in more prosaic and ubiquitous ways in their daily activities; disciplinary power spreads across this space, with the result that coercive authority organizes subjects "in the totality of their activities" $(2000,24)$ and becomes "inseparable from [their] subjectivity itself" $(2000,329)$. Whereas workplace supervisors previously amassed information and assembled data about individuals and groups; today, that information is collected by supermarkets, online merchants, and internet service providers that track purchasing patterns and online browsing habits. Surveillance, no longer the purview of industrial 
managers, is accomplished largely by privately owned surveillance networks that police both so-called public and so-called private space. Working from home affords workers less time under the direct disciplinary gaze of a supervisor, but keystrokes, transactions, and phone calls continue to register locations, preferences, and behaviors. In other words, discipline - the observation, exercise, and examination of bodies that Foucault rooted in the confined institutions of work, school, hospital, and prison — has shifted from our producer to our consumer activities. Zygmunt Bauman explains this in his observation that we now live in a consumer - rather than a producer - society, since the "role once played by work in linking together individual motives, social integration and systemic reproduction, has now been assigned to consumer activity" (1998, 27; 2007, 52-81). Hence, in Fast Food Nation, the terms of factory surveillance and organization-especially in the opening, gripping sections and in the rallying epilogue - are used to describe not how we produce, but how we consume.

Bryan Turner (1982) noted decades ago that the quantification and standardization of activities that Foucault discusses were becoming less visibly deployed in discourses of industrial management and more in the disciplinary discourses of diet and nutrition. Bodies, Turner argued, become useful and predictable not because supervisors impose timetables and regulate coffee breaks, but because individuals track their own calories, carbs, and grams of fat. More recently, Mark Greif (2004) has presented the ritualistic aspects of exercise - especially the systematic counting of times, repetitions, and heart rate - as a "set of forms of bodily self-regulation which drag the last vestiges of biological life into the light as a social attraction." In other words, while discipline was formerly imposed, hierarchical, and discrete, discourses of consumption from diet to exercise have regularized a form of discipline that is voluntary, democratic, and pervasive. My boss no longer watches me work and calculates how long it takes me to assemble a widget, but I tabulate my reps at the gym and monitor my own cholesterol, thus producing the same kind of knowledge about me. I learn the inner truth of myself not by expressing myself in my work, but by seeing my consumer profile at Amazon.com. My position in cultural politics depends not on my status as worker or owner, but my preference for NASCAR or lattes. This is surely why the factory metaphor travels to so many domains of life: the concerns about alienation and control that inhere in the metaphor are not anachronistic in an age of casualized labor; they are instead generalized to work, leisure, and politics.

The distinctive marks of a consumer society are also visible in the changing face of wealth in the U.S. Whereas Sinclair wrote at a time when wealth was generally generated through production, Schlosser writes in a historical period in which wealth is primarily produced through consumption. Today, major economic transactions increasingly take the form of currency speculations and investments, the issuance of credit is bigger business than producing machinery, and more wealth is produced by servicing debt than by engaging in productive labor. ${ }^{13}$ Indeed, consumption has become the most important type of production, consumers the most productive of producers, since consumers produce the most 
valuable of all commodities: consumers produce debt. In which case, Schlosser does not merely repeat the guiding assumptions of various anthropological studies of cuisine when he claims that our diet says more about our identity than our job, he asserts the defining feature of a consumer society: it is consumption, as much as production, that creates value.

Though Sinclair and Schlosser each draw our attention to different social landmarks, the former to enclosed institutions of production and the latter to dispersed practices of consumption, they appeal to the same anxieties about freedom and control. In Schlosser's book, the normalization and management that inheres in the metaphor of a factory farm is distributed to each moment in the lifespan of industrial foodstuffs - from the engineering and harvesting of potatoes, to the manufacture of homogenized desire in marketing boardrooms, to the deskilling of culinary labor in school lunchrooms, to the coordination of foot traffic at retail establishments, to the consumption and storage of surplus calories in individual bodies. Schlosser deftly applies the metaphor to the manufacturing plant, the feedlot, mass society, and the individual body, and his book's popularity reflects a social condition in which no domain of life is immune to the disciplinary power of the market. The metaphor itself signals an uncomfortable yet seemingly unavoidable consolidation of the industrial and the organic, with the logic of industrial capitalism invading the most pristine and romanticized of American landscapes: the family farm and the dining room table. As ever more dimensions of daily life reveal this consolidation, we can expect the metaphor to continue to structure the increasingly politicized debates over food in the United States.

\section{Do You Want History with That?}

Whether emphasizing production or consumption, the disparate approaches to factory farming share a commitment to revelatory critique, implying that publicizing the hidden practices of production will inspire transformation in habits of consumption. In Sinclair, this means showing how sausage is produced; in Singer, how animals are tortured; in Schlosser, how workers are indentured and children exploited. Singer explains that he wrote his chapter on factory farming "because the general public is largely ignorant of the suffering these methods involve" $(1975,145)$; Schlosser's subtitle promises to throw light upon The Dark Side of the All-American Meal; and discussing proposals to print pictures of cows' living conditions on packages of ground beef, Pollan asks us to "[i]magine how quickly this sort of transparency would force a revolution in our food chain" (2001, 2006, 244-5). Books like Ruth Harrison's Animal Machines (1964), Andrew Johnson's Factory Farming (1991), and Sue Coe's Dead Meat (1995) include graphic images of factory farms and clearly operate with the presumption that if confronted with the reality of factory farms, the markets for their products will collapse. The idea is to create what butcher/journalist Jon Mooallem (2005) calls “digestive dissonance," to upset readers' stomachs such 




Figure 2: Sue Coe, Factory Pharm, (suecoe copyright 2009).

that they rethink their taste for the products of industrial agriculture. Sinclair famously captured this dissonance in reflecting on reception of The Jungle: "I aimed at the public's heart, and by accident I hit the stomach" (Sinclair 1906b, 594).

Such appeals to digestive dissonance effectively push together the industrial and the organic, production and consumption, in a way that illuminates the fallacy of the "thing in itself" fetish, and challenges the unabashed presentism of global capital by asking the diner to have a healthy dose of history along with their burger. As an analogic critique, they endeavor to connect practices of consumption with those of production, drawing attention to the easy-to-ignore social relations embodied in a ready-to-eat hamburger or super-sized cola. They question the distinction between production and consumption by highlighting how, as Marx puts it, "production is simultaneously consumption," since, e.g., farming burns fuel, and "consumption is simultaneously also production," since eating produces human labor power (1903/1970a: 195-9). The metaphor of a factory farm itself reveals this slippage, as its broad usage reveals how particular types of farming consume inordinate quantities of natural resources, how slaughterhouse and fast food labor destroy human populations, and how particular modes of consumption produce particular types of labor markets.

But as Mooallem notes, the idea of revelatory critique as political strategy rests on the assumption that individual consumers will actually act on their digestive dissonance, an assumption that often sits clumsily alongside countervailing evidence. After forty years of publicizing feedlot conditions, meat consumption is not down even among meat writers. Schlosser and Pollan, for instance, two of the system's harshest and most visible critics, admit that they continue to eat food from factory farms and that the relative affordability of such products all but ensures that others will, too. Similarly, the leaked videos of deplorable feedlot conditions that circulated widely through network news and internet sites in 2008 inspired tremendous shame and indignation among the population, but do 
not appear to have significantly effected hamburger sales. Appeals to digestive dissonance trade in the idea that the solution to factory farming lies in individual responsibility; in Johnson (1991), for example, the section on economics is called "Practical Choices," and the section on ethics is called "Moral Choices." Lappé $(1971,8)$ states that she writes about food because, in an increasingly complex world, our food intake is the one thing we can control. Even in writings as thoughtful and sophisticated as Schlosser's and Pollan's, the payoff is a recommendation to boycott the fast food industry. After Schlosser spends 270 pages detailing how food production practices are entrenched in an opaque system of international economic pressures, scientific pursuits of efficiency, ecological imperatives, and a hundred or so years of unwise and corrupt public policy, he ends his book with a call to individual consumptive responsibility: "A good boycott, a refusal to buy, can speak much louder than words. . . . It's not too late. Even in this fast food nation, you can still have it your way" $(2001,269-70) .{ }^{14}$

This strategy of responsible consumption dominates discussions of the politics of food, and it elevates the consumption of organic, local, or "slow" foods to the status of political action. ${ }^{15}$ Whereas Sinclair's focus on the production of industrial food informed obvious political strategies of industrial regulation and union organization, the appeals to digestive dissonance put the burden on an already strapped consumer for paying more money for goods that make them feel better about themselves, and ultimately explains the marginalization of alternative farming as a function of consumer preference. If people wanted ethically or sustainably raised food, they'd head over to their local farmer's market (or maybe Whole Foods) and buy it. They typically fail to account for the myriad obstacles to indulging digestive dissonance - obstacles such as the federal subsidies for large-scale farming that raise the relative price of organic and local produce, labor markets that demand reliance upon the quick and reliable fuel offered by fast food outlets, the comparative market advantage afforded to franchises over independently owned restaurants, the depleted tax base that encourages public schools to sell junk food on campus, and the efficacy of aggressive marketing campaigns in winning the hearts and minds of America's youth.

If, as I have suggested, the factory farm is a pervasive metaphor because it corresponds to an experiential gestalt of powerlessness, such claims that individual consumers can make a difference might seem peculiar, invoking an efficacy that is itself called into question by the metaphor. It is this slippage between production, consumption, and politics, however, that renders the factory farm literature both so compelling and so distressing - forcing with such facility the realization of the untenability of the myth of the free consumer while at the same time casting consumerism as political resistance. In a more severe idiom, calls for responsible consumption might seem like simple false consciousness, blindly asserting individual empowerment as a means to avoiding the structural dynamics preventing it. But as suggested earlier, we might instead see the turn to responsible consumption as itself a reflection of the real lack of opportunity for more conventional forms of politics. Drawing again on Bauman, if one of the 
hallmarks of a consumer society is that social integration is facilitated through consumer relations, it should come as little surprise that Americans experience and understand politics in the terms of consumption. The appeal to digestive dissonance is itself an expression of the experiential gestalt of global capitalism, and the literature offers not so much an end to factory farming as a promise of political power in the only place it can be conceived: the market. It reflects an experiential gestalt in which consumption is not only a central mode of production but also the primary mode of social and political engagement.

\section{Notes}

Thanks to the many colleagues and audiences who helped me work through these ideas: Asma Abbas, Ryan Carey, Maryann Tebben, and the division of Social Sciences of Bard College at Simon's Rock; Mike Lipscomb and the departments of Political Science and Environmental Studies at Winthrop University; and Katie Terezakis and the department of Philosophy at the Rochester Institute of Technology. Thanks also to Johnny Goldfinger, David Katzman, Elizabeth Mazzolini, Rich Newman, and three anonymous reviewers for American Studies for generous feedback on earlier drafts. Special thanks to the Bill and Carol Fox Center for Humanistic Inquiry at Emory University for funding this research.

1. In the second edition of the Principles, Marshall moved this statement from a discussion of large-scale industry to a footnote in his discussion of land usage. Though this is the earliest use of the term recorded in the Oxford English Dictionary, Marshall's phrasing ("what have been called. ...") clearly indicates that he is not coining the term. The term is largely absent from the concurrent debates about industrial agriculture across Europe (e.g., Kautsky 1899/1988; Lenin $1899 / 1956)$, though this is at least partly due to translation and linguistic chance, since much of the appeal of the term "factory farm" comes from its alliterative quality. Lenin, for instance, seems to prefer the less poetic but roughly equivalent term "commercial agriculture."

2. See Schlosser (2001, 199-204). Upon visiting an industrial feedlot, Michael Pollan compares it to fourteenth-century London, with the workings of digestion "vividly on display, the foodstuffs coming in, the streams of waste going out. The crowding into tight quarters of recent arrivals from all over, together with the lack of sanitation, has always been a recipe for disease. The only reason contemporary animal cities aren't as plague ridden or pestilential as their medieval counterparts is a single historical anomaly: the modern antibiotic" $(2006,73)$. On the threat of epidemics in agriculture more generally, see Diamond (1997, 202-7).

3. For example, though cattle, as ruminants, are uniquely qualified to digest grass, industrial cattle populations today subsist almost entirely on grain, such as corn. This diet brings them to slaughter weight nearly four times as fast, but the cost of this rapid growth is a set of digestive problems that would be fatal without heavy doses of antibiotics (Pollan 2006, 67-77).

4. As one rancher tells Pollan, "I'd love to give up hormones. . . The cattle could get along better without them. But the market signal's not there, and as long as my competitor's doing it, I've got to do it, too" (2002).

5. The term does show up in radical texts from the 1930s, such as Carey McWilliams's Factories in the Fields (1939) and various publications from the American communist party (see Shover 1964).

6. It is surely noteworthy that when Animal Machines appeared in 1964, it carried an enthusiastic preface from Rachel Carson, whose Silent Spring was released just two years earlier.

7. There are other arguments against factory farming, such as Harvey Levenstein's (1988, 1993 ) concern about its homogenization of American cuisine. But the three I've focused on-ecological, ethical, and economic - seem primary.

8. Vegetarians have capitalized on this connection by transposing the film to an industrial feedlot in the popular online animation "The Meatrix" (www.meatrix.com).

9. As a corollary, this resonance might also explain why Orville Schell's (1978) Modern Meat never really took hold of the popular imagination, despite unqualified praise from journalists and food scholars; Schell's equally alliterative term "pharmaceutical farm" never became a popular structural metaphor because it is difficult to imagine the various institutions of global capitalism as so many pharmacies.

10. In a preface to How to Live, former President William Howard Taft, who had lost 80 pounds since leaving the White House, recommends the book's program for counting calories as a way to avoid "lowered physical efficiency and chronic, preventable disease" $(v-v i)$. By 1918, the book was in its fifteenth edition. 
11. By contrast, Schlosser offers a curiously romantic portrayal of the Chicago meatpacking district (156-7), presumably where the logic of industrial manufacture was still contained at the workplace.

12. Hardt and Negri are here drawing on Deleuze (1997), who argues that Foucault himself stopped talking about "disciplinary society" and came instead to talk about "societies of control," since "everyone knows that these institutions [prisons, hospitals, factories, schools, families] are in more or less terminal decline" (178). This is a curious - and curiously influential - reading of Foucault, and one for which Deleuze does not provide any citation. Hardt and Negri also pick up on Deleuze's terminology here, though their argument that this is a generalization rather than a transformation in discipline begs the question as to why we need a new term such as "society of control."

13. The financial crisis of 2008 has revealed just how much the global economy is predicated on the production (and overproduction) of debt. Note also how the current war effort in the United States has been accompanied by a reversal of the typical stance that citizens must sacrifice in times of military struggle; now, we support the war not by saving, but by going shopping. For details of the exponential increase of debt and financial assets relative to GDP since WWII, see Henwood (1997, 58-62; 2003, 191-195).

14. Super Size Me ends on a similar note, calling upon consumers to stop buying fast food: "If this ever-growing paradigm is going to shift, it's up to you." Notably, the Hollywood adaptation of Fast Food Nation (2006) ends quite differently: after a feckless and fruitless attempt at industrial sabotage, the film's protagonists abandon their crusades against industrial food and dolefully return to their jobs at the slaughterhouse or marketing department. The film flopped at the box office, perhaps because it failed to offer a political vision that could speak to the anxieties about powerlessness, except by confirming them.

15. For recent examples, see Pollan (2006), Kingsolver (2007), and McKibben (2007). For a more substantial discussion of this literature in particular, see Lavin (2009).

\section{Works Cited}

Bauman, Zygmunt. 1998. Work, Consumerism and the New Poor. Buckingham, U.K.: Open University Press. 2007. Consuming Life. Cambridge, U.K.: Polity Press.

Boyle, T. Coraghessan. 1993. Road to Wellville. New York: Penguin.

Butler, Octavia. 1987. Dawn. New York: Warner Books.

Coe, Sue. 1995. Dead Meat. New York: 4 Walls 8 Windows.

Coupland, Douglas. 1991. Generation X. New York: St. Martin's Press.

Critser, Greg. 2005. Generation Rx: How Prescription Drugs Are Altering American Lives, Minds, and Bodies. Boston: Houghton Mifflin.

Deleuze, Gilles. 1997. "Postscript on Societies of Control," in his Negotiations 1972-1990. Trans. Martin Joughin. New York: Columbia University Press.

Diamond, Jared. 1997. Guns, Germs, and Steel: The Fates of Human Societies. New York: Norton.

Douglas, Mary. 1966. Purity and Danger: An Analysis of the Concepts of Pollution and Taboo. New York: Routledge.

Fisher, Irving and Eugene Lyman Fisk. 1915. How To Live: Rules for Healthful Living Based on Modern Science. New York: Funk \& Wagnalls Company. Fitzgerald, Deborah. 2003. Every Farm a Factory: The Industrial Ideal in American Agriculture. New Haven: Yale University Press.

Foucault, Michel. 1977. Discipline and Punish: The Birth of the Prison. Trans.

A. Sheridan. New York: Vintage.

Frank, Thomas. 2000. One Market Under God: Extreme Capitalism, Market Populism, and the End of Economic Democracy. New York: Anchor.

Greif, Mark. 2004. "Against Exercise." $n+1,1(1)$. 
Hardt, Michael and Negri, Antonio. 2000. Empire. Cambridge: Harvard University Press.

2004. Multitude: War and Democracy in the Age of Empire. New York: Penguin.

Harrison, Ruth. 1964. Animal Machines: The New Factory Farming Industry. London: Vincent Stuart Ltd.

Henwood, Doug. 1997. Wall Street: How It Works and for Whom. New York: Verso.

2003. After the New Economy: The Binge and the Hangover That Won't Go Away. New York: Verso.

Ishiguro, Kazuo. 2005. Never Let Me Go. New York: Knopf.

Johnson, Andrew. 1991. Factory Farming. Oxford: Blackwell Publishers.

Kautsky, Karl. 1988. The Agrarian Question, 2 vols. Trans. Pete Burgess. London: Billing \& Sons Ltd. First published 1899.

Kingsolver, Barbara. 2007. Animal, Vegetable, Miracle: A Year of Food Life. New York: Harper Collins.

Lakoff, George and Johnson, Mark. 1980. Metaphors We Live By. Chicago: University of Chicago Press.

Lavin, Chad. 2009. "The Year of Eating Politically." Theory \& Event 12, no. 2 (June).

Lappé, Frances Moore. 1971. Diet For a Small Planet. New York: Ballantine.

Lenin, V.I. 1956. The Development of Capitalism in Russia. Moscow: Foreign Languages Publishing House. First published 1899.

Levenstein, Harvey. 1988. Revolution at the Table: The Transformation of the American Diet. New York: Oxford University Press. . 1993. The Paradox of Plenty: A Social History of Eating in America. New York: Oxford University Press.

Manning, Richard. 2004. Against the Grain: How Agriculture Hijacked Civilization. New York: North Point Press. . 2004a. "The Oil We Eat." Harper's, February: 37-45.

Marshall, Alfred. 1961. Principles of Economics, Ninth (Variorum) Edition, volume I. London: MacMillan and Co, Ltd. First published1890.

Marx, Karl. 1970. Critique of Hegel's 'Philosophy of Right.' Trans. A. Jolin and J. O'Malley. Cambridge: Cambridge University Press. First published 1843. . 1970a. Contribution to the Critique of Political Economy. Ed. Maurice Dobb. New York: International Publishers. First published 1903. . 1977. Capital, Volume 1. Trans. Ben Fowkes. New York: Penguin. First published 1867.

McKibben, Bill. 2007. Deep Economy: The Wealth of Communities and the Durable Future. New York: Times Books.

McWilliams, Carey. 1939. Factories in the Field: The Story of Migratory Farm Labor in California. Boston, MA: Little, Brown.

Mooallem, Jon. 2005. "Carnivores, Capitalists, and the Meat We Read." The Believer 3, no. 8, October. 
Moynihan, Ray and Alan Cassels. 2005. Selling Sickness: How the World's Biggest Pharmaceutical Companies Are Turning Us All Into Patients. New York: Nation Books.

Peters, Tom. 1992. Liberation Management: Necessary Disorganization for the Nanosecond Nineties. New York: Knopf.

. 1999. The Circle of Innovation: You Can't Shrink Your Way to Greatness. New York: Vintage.

Pollan, Michael. 2001. "Produce Politics." The New York Times Magazine (January 14).

. 2002. "Power Steer." The New York Times Magazine (March 31).

. 2006. The Omnivore's Dilemma: A Natural History of Four Meals. New York: Penguin.

Rabinbach, Anson. 1990. The Human Motor: Energy, Fatigue, and the Origins of Modernity. New York: Basic Books.

Rifkin, Jeremy. 1992. Beyond Beef: The Rise and Fall of the Cattle Culture. New York: Penguin.

Robbins, John. 1987. Diet for a New America: How Your Food Choices Affect Your Health, Happiness and the Future of Life on Earth. Walpole, NH: Stillpoint Publishing.

Sassen, Saksia. 1996. Losing Control?: Sovereignty In an Age of Globalization. New York: Columbia University Press.

Schell, Orville. 1978. Modern Meat: Antibiotics, Hormones, and the Pharmaceutical Farm. New York: Vintage.

Schlosser, Eric. 2001. Fast Food Nation: The Dark Side of the All-American Meal. Boston: Houghton Mifflin.

Shover, John. 1964. "The Communist Party and the Midwest Farm Crisis of 1933." The Journal of American History 51, no. 2.

Sinclair, Upton. 1906a. The Jungle. New York: Dover. 1906b. "What Life Means to Me." The Cosmopolitan 41, no. 6 (October).

Singer, Peter. 1975. Animal Liberation. New York: Harper Collins.

Turner, Bryan. 1982. "The Discourse of Diet." Theory, Culture \& Society 1, no. 1.

Weber, Max. 1930. The Protestant Ethic and the Spirit of Capitalism. Trans. Talcott Parsons. Los Angeles: Roxbury Publishing Company. First published 1904. 